\title{
Characterization of Swallowing Sounds with the Use of Sonar Doppler in Full-Term and Preterm Newborns
}

\author{
Hellen Nataly Correia Lagos ${ }^{1,2}$ Rosane Sampaio Santos ${ }^{1,3}$ Edna Marcia da Silva Abdulmassih ${ }^{1,4}$ \\ Liliane Friedrich Gallinea ${ }^{2,5}$ Mariangela Langone ${ }^{2}$
}

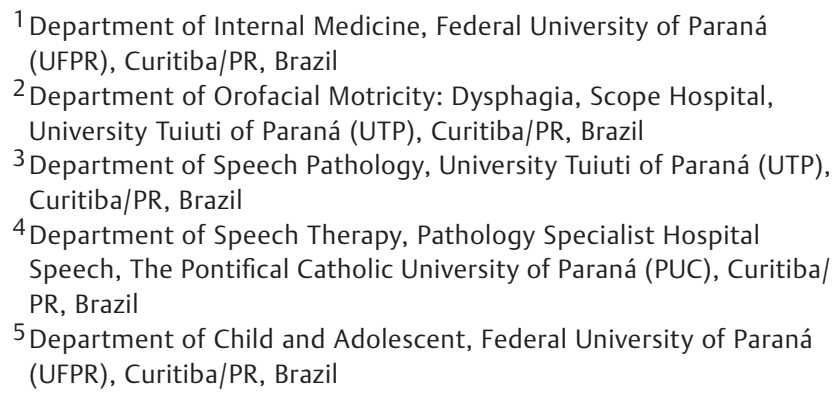

Address for correspondence Hellen Nataly Correia Lagos, MSc, Rua Santa Catarina, 427, ap24, Bairro Água Verde, Curitiba, Paraná, Brazil (e-mail: hellennataly@gmail.com).

Int Arch Otorhinolaryngol 2013;17:383-386.

\begin{abstract}
Keywords

- deglutition

- infant

- newborn

- Doppler effect

Introduction Technological advances have provided a large variety of instruments to view the swallowing event, aiding in the evaluation, diagnosis, and monitoring of disturbances. These advances include electromyography of the surface, dynamic video fluoroscopy, and most recently sonar Doppler.

Objective To characterize swallowing sounds in typical children through the use of sonar Doppler.

Method Thirty newborns participated in this prospective study. All newborns received breast milk through either their mother's breasts or bottles during data collection. The newborns were placed in either right lateral or left lateral positions when given breast milk through their mother's breasts and in a sitting position when given a bottle. There were five variables measured: initial frequency of sound wave (Fol), frequency of the first peak of the sound wave (FoP1), frequency of the second peak of the sound wave (FoP2), initial intensity and final sound wave (II and IF), and swallowing length (T), the time elapsed from the beginning until the end of the analyzed acoustic signal measured by the audio signal, in seconds.

Results The values obtained in the initial frequency of the babies had a mean of 850 $\mathrm{Hz}$. In terms of frequency of first peak, only three presented with a subtle peak, which was due to the elevated larynx position.

Conclusion The use of sonar Doppler as a complementary exam for clinical evaluations is of upmost importance because it is nonintrusive and painless, and it is not necessary to place patients in a special room or expose them to radiation.
\end{abstract}

Copyright $\odot 2013$ by Thieme Publicações DOI http://dx.doi.org/ Ltda, Rio de Janeiro, Brazil $10.1055 / \mathrm{s}-0033-1353369$. ISSN 1809-9777. 


\section{Introduction}

Eating is a vital function in any age and especially for a newborn. Eating orally for newborns is a complex activity that requires coordination of sucking, breathing, and swallowing functions so that it does not risk aspiration. ${ }^{1}$

Efficient and secure eating requires not only sucking, but also coordination in breathing with sucking and swallowing. This involves a combination of functions from the lips, jaw, tongue, pharynx, larynx, and esophagus. ${ }^{2}$ Therefore the coordination of sucking, swallowing, and breathing cannot be completely acquired in premature babies when oral eating is introduced. ${ }^{3}$

Premature babies have a high risk of eating difficulties. Their neurologic immaturity, abnormal muscular tone, disabled oral reflexes, general weakness, and difficulties in autoregulation could lower the quality of their oral motor abilities, interfering in the synchronization of sucking, swallowing, and breathing, which is a primary oral motor mechanism, and the amount ingested. ${ }^{4,5}$

Technological advances have provided a large variety of instruments to view the swallowing event, aiding in the evaluation, diagnosis, and monitoring of disturbances. These advances include electromyography of the surface, ${ }^{6}$ sonograms of swallowing action, ${ }^{7}$ swallowing endoscopies, dynamic video fluoroscopy of swallowing, ${ }^{8,9}$ virtual endoscopy through a computerized tomography with reconstructive software, ${ }^{10}$ cervical auscultation through a microphone and accelerometer, ${ }^{11}$ and most recently sonar Doppler. ${ }^{12-15}$

These procedures are not invasive and are used to contribute to the evaluations of swallowing. Experiments with analytical computations of swallowing sounds have been made, and these studies demonstrate the usefulness of digital sounds of swallowing for duration measurements and the amplitude of sound waves. ${ }^{13,16,17}$

The technical development of sonar Doppler as a method for evaluating swallowing makes comprehension of the findings in swallowing disorders necessary. Studies on the use of sonar Doppler in evaluating swallowing up to now show normal swallowing sound waves in all age groups without pointing to findings referring to swallowing disturbances. $^{12-15}$

Sonar Doppler of the larynx is a noninvasive technique that causes no pain or exposure to radiation. There is no need for sedatives, and it is quick and easy to use in infants. Results can be recorded with sound analysis software. The equipment is of good quality and has a widespread availability-it is available in most hospitals and clinics. There is no need for further investment in new equipment because the equipment already exists for use in other parts of the body. The equipment is also easy to transport.

Sonar Doppler does not substitute for video fluoroscopy and video endoscopy of swallowing, but it could help in the evaluation of functional swallowing and in the monitoring of treatment as a biofeedback, in which muscular activity can be converted into an audio stimulus, visual stimulus, or both.

The objective of this study was to characterize swallowing sounds in typical children using sonar Doppler.

\section{Methods}

The present observational study occurred March 2010 through October 2011. The study was approved by the Ethics and Research Committee through the registration of CEP: 2099.266/2009-11, on March 12, 2010.

Participants included 30 premature newborns. Guardians were informed of the study and were solicited for the authorization of participation of newborn babies. Once they accepted, they were asked to sign terms of agreement and authorization.

Criteria for inclusion in study was premature newborn of either sex, born in a public institution in Curitiba city, with adequate sucking and swallowing, substantiated through previous speech evaluations. Babies who showed breathing difficulties in coordination of breathing and swallowing or any other structural and/or functional alterations that could interfere with swallowing were excluded. Newborns with any diagnosis of neurologic problems or associated syndromes and high-risk newborns with pathologies that could complicate alterations in the stomatognathic system were also excluded.

To record the sound, a portal ultrasonic detector was used (model DF-4001, Martec brand), with a plain disc transducer, of only one crystal, providing interface to the sonar Doppler. The ultrasound frequency was $2.5 \mathrm{~Hz}$, with output $10 \mathrm{~mW} /$ $\mathrm{cm}^{2}$ and an output power of $1 \mathrm{~W}$ sound. The Doppler equipment was coupled with a standard IBM microcomputer, with a Pentium 200-MHz processor, $32 \mathrm{MB}$ of RAM, video plate with high color support ( 16 bits; $800 \times 600$ ), CD-ROM drive of $8 \times$, sound plate, and speakers. The operating system was Windows 98 and VOX metria Software was used. ${ }^{18}$

All newborns received breast milk through either their mother's breasts or bottles during data collection. The newborns were placed in either right lateral or left lateral positions when given breast milk through their mother's breasts and in a sitting position when given a bottle. As an indicator for the best location of the positioning of the transducer, a presentation by Takahashi et al was used, ${ }^{19}$ which showed the best adaptation of the transducer and the best capture of sonorous signal, location 11, above the lateral region of the trachea, inferior to the cricoids cartilage. The transducer was adjusted onto the neck using a gel contact to facilitate the contact of the transducer and skin. The transducer's bundle was positioned to form an angle of 30 to 60 degrees.

Five variables were measured: initial frequency of sound wave (FoI), frequency of the first peak of the sound wave (FoP1), frequency of the second peak of the sound wave (FoP2), initial intensity and final sound wave (II and IF), and swallowing length $(\mathrm{T})$, the time elapsed from the beginning until the end of the analyzed acoustic signal measured by the audio signal, in seconds.

\section{Results}

Of the babies evaluated, 50\% were male and 50\% were females; they all were 48 hours old. 
Table 1 Mean initial frequency $(\mathrm{Hz})$ in newborns

\begin{tabular}{|l|l|}
\hline Consistency & Newborns \\
\hline Liquid & 850 \\
\hline
\end{tabular}

Table 2 Mean frequency of first peak in newborns

\begin{tabular}{|l|l|}
\hline Consistency & Newborns \\
\hline Liquid & $*$ \\
\hline
\end{tabular}

${ }^{*}$ Not obtained peak value, was a subtle peak.

Table 3 Mean frequency $(\mathrm{Hz})$ of the second peak in newborns

\begin{tabular}{|l|l|}
\hline Consistency & Newborns \\
\hline Liquid & 1087 \\
\hline
\end{tabular}

The values obtained in the initial frequency had a mean of $850 \mathrm{~Hz}$ as shown in - Table 1. In terms of frequency of first peak, only three presented with a subtle peak, due to the elevated larynx position (-Table 2 ). - Table 3 shows the frequency of the second peak standards found in newborns. The mean of the initial intensity of adults and newborns are shown in - Table 4. Finally, - Table 5 shows swallowing time in the group studied.

\section{Discussion}

Technological advances have brought about instruments with great variability in applications, aiding in the search of evaluations, diagnostics, and monitoring of swallowing disorders. Tools that detect with precision alterations in the swallowing process are important not only scientifically but also clinically. In the research field, these tools validate objective data by greatly reducing subjectivity in the individuals doing the evaluations. In clinics, they could facilitate decisions made by therapists, indicating which therapeutic maneuvers should be used or which eating consistency is the safest to digest. ${ }^{17}$

Table 4 Mean of initial and final intensity $(\mathrm{dB})$ in newborns

\begin{tabular}{|l|l|l|}
\hline Intensity & Newborns & Adults \\
\hline Initial & 72 & 51 \\
\hline Final & 91 & 91 \\
\hline
\end{tabular}

Table 5 Mean swallowing time (s) in newborns

\begin{tabular}{|l|l|}
\hline Time & Newborns \\
\hline T1 & 0.53 \\
\hline T2 & 1.04 \\
\hline T3 & 2.08 \\
\hline
\end{tabular}

According to some authors, ${ }^{20}$ the mean initial frequency of the swallowing sound in adults is FoI $567 \mathrm{~Hz}$; in the present study it was observed that in newborns the mean found was FoI $850 \mathrm{~Hz}$, showing a more acute frequency compared with adults.

Findings in first peak in adults are characterized by a weak signal associated with laryngeal lift, and the passage of cake through the pharynx ${ }^{21}$ was FoP1 $905 \mathrm{~Hz}$; of the 30 newborns analyzed only three presented with sufficient initial peak. This can be explained through the elevated position of the larynx.

Frequency of the second peak represents a strong sound associated with the opening of the cricopharyngeal ${ }^{21}$; in adults, the mean is FoP2 $1.087 \mathrm{~Hz}$, very close frequencies between the two peaks.

The mean of initial and final intensities found in adults was, respectively, $51 \mathrm{~dB}$ and $91 \mathrm{~dB}$; in newborns the mean was $72 \mathrm{~dB}$ and $91 \mathrm{~dB}$.

Finally, the times found in swallowing standards in adults were T1: 1.33 seconds; T2: 1.67 seconds; T3: 1.85 seconds; and in newborns they were $\mathrm{T} 1: 0.53$ seconds, $\mathrm{T} 2: 1.04 \mathrm{sec}-$ onds, T3: 2.08 seconds.

As found in these data, sonar Doppler can be used as a method of evaluation for swallowing, giving more support during evaluations, treatment, and diagnosis of a dysphasic patient.

\section{Conclusion}

The use of sonar Doppler as a complementary exam for clinical evaluations is of upmost importance because it is nonintrusive and painless, and it is not necessary to place patients in a special room or expose them to radiation. Not only is it unnecessary to sedate the patient, the time of use is short, making it easy to use in infants. The findings could be recorded in analytic sound software, linked in any portal computer, using portal, cost-effective equipment.

\section{References}

1 Silva-Munhoz LF, Bühler KEB. Achados fluoroscópicos da deglutição: comparação entre recém-nascidos pré-termo e recém-nascidos de termo. Jornal Soc Bras Fonoaudiol 2011;23:206-213

2 Mizuno K, Ueda A. The maturation and coordination of sucking, swallowing, and respiration in preterm infants. J Pediatr 2003; 142:36-40

3 Quintella T, Silva AA, Botelho MIMR. Distúrbio da deglutição (e aspiração) na infância. In: Furkim AM, Santini CS, eds. Disfagias Orofaríngeas. Carapicuíba, Brazil: Pró-Fono; 1999:61-96

4 Morris SE, Klein MD. Pre-Feeding Skills: A Comprehensive Resource for Feeding Development. Tucson, AZ: Therapy Skill Builders; 1987

5 Silva RNM. Efeitos da Sucção não-nutritiva no Prematuro. In: Lopes SMB, Lopes JM. Follow up do recém-nascido de Alto Risco. Rio de Janeiro, Brazil: Medsi; 1999:309-316

6 Crary MA, Baldwin BO. Surface eletromyographic characteristics of swallowing in dysphagia secondary to brainstem stroke. Dysphagia 1997;12:189-197

7 Brown PB, Sonies BC. Diagnostic methods to evaluate swallowing other than barium contrast. In: Perlman AL, Schulze-Delrie K, eds. 
Deglution and Its Disorders. San Diego, CA: Singular Publishing Group; 1997:227-253

8 Macedo-Filho ED. Estudo comparativo entre a Videoendoscopia da Deglutição (VED) e a Videofluoroscopia (VFC) na Avaliação da Disfagia Orofaríngea Pós-Acidente Vascular Cerebral (AVC) [Tese de doutorado]. Curitiba, Brazil: Universidade Federal do Paraná; 2001

9 Hartnick CJ, Hartley BE, Miller C, Willging JP. Pediatric fiberoptic endoscopic evaluation of swallowing. Ann Otol Rhinol Laryngol 2000;109:996-999

10 Burke AJ, et al. Evaluation of airway obstruction using virtual endoscopy. Laryngoscope 2000;1110:23-29

11 McKaig TN. Ausculta: Cervical e Torácica. In: Furkin AM, Santini CS, eds. São Paulo, Brazil: Pro-Fono; 1999:171-187

12 Santos RS, Filho EDM. Sonar Doppler as an instrument of deglutition evaluation. Int Arch Otorhinolaryngol 2006;10(3):182-191

13 Bernardes TG, Jukiweski A, Santos RS. Uso do sonar doppler como biofeedback da deglutição em pacientes com doença de Parkinson [Dissertação de mestrado]. Curitiba, Brazil: Universidade Tuiuti do Paraná; 2008
14 Cagliari CF, Jurkiewicz AL, Santos RS, Marques JM. Doppler sonar analysis of swallowing sounds in normal pediatric individuals. Braz J Otorhinolaryngol 2009;75:706-715

15 Sória FS. Padrão de Normalidade da Deglutição em Idoso através do Sonar Doppler [Dissertação de mestrado]. Curitiba, Brazil: Universidade Tuiuti do Paraná; 2010

16 Youmans SR, Stierwalt JAG. An acoustic profile of normal swallowing. Dysphagia 2005;20:195-209

17 Spadotto AA. Análise Quantitativa do Sinal da Deglutição. [Tese de doutorado]. São Carlos, Brazil: Universidade de São Paulo; 2009

18 Behlau M. VoxMetria: Software para Análise de Voz e Qualidade Vocal. São Paulo: CTS Informática; 2003

19 Takahashi K, Groher ME, Michi K. Methodology for detecting swallowing sounds. Dysphagia 1994;9:54-62

20 Cichero JAY, Murdoch BE. Detection of swallowing sounds: methodology revisited. Dysphagia 2002;17:40-49

21 Hamlet SL, Patterson RL, Fleming SM, Jones LA. Sounds of swallowing following total laryngectomy. Dysphagia 1992;7: 160-165 